\title{
Molecular Mechanisms of Hypoglycemic and Antioxidative Effects of Phyllanthus Amarus on Streptozotocin-Induced Diabetic Rats
}

\author{
Mahamadou Danda Amina ${ }^{1}$, Attakpa Sèlidji Eugène ${ }^{1 *}$, Sangare Maxime Machioud ${ }^{1}$, Guinnin Félix ${ }^{1}$, Akotegnon Rodrigue ${ }^{1}$, \\ Amoussa Abdou Madjid ${ }^{2}$, Lagnika Latifou ${ }^{2}$, Baba-Moussa Lamine ${ }^{3}$, Bialli Seri ${ }^{4}$ and Naim Akhtar Khan ${ }^{5}$ \\ ${ }^{1}$ Laboratoire de Physiopathologie Moléculaire et Toxicologie, Department of Animal Physiology, Faculty of Science and Technology, 01 BP: \\ 4521 Cotonou, University of Abomey-calavi, Benin \\ ${ }^{2}$ Unité de Biochimie et de Biologie Moléculaire, Laboratory of Biochemistry and Bioactives \\ Natural Substances, Faculty of Science and Technology, University of Abomey-calavi 01 BP: 4521 Cotonou, Benin \\ ${ }^{3}$ Laboratoire de Biologie et de Typage Moléculaire en Microbiologie, Faculty of Science and Technology 05 BP 1604 Cotonou, University of \\ Abomey-calavi, Benin \\ ${ }^{4}$ Laboratoire de Neurosciences, Unité de Formation Biosciences 22 BP 582 Abidjan 22 Université de Cocody-Abidjan (Rép. de Côte-d'Ivoire) \\ ${ }^{5}$ INSERM U866, Physiologie de la Nutrition \& Toxicologie. Université de Bourgogne. 6, Boulevard Gabriel, U.F.R Sciences de la Vie, Dijon 21000, \\ France
}

Received: July 09,2018; Accepted: July 27,2018; Published: August 06,2018

*Corresponding author: ATTAKPA Sèlidji Eugène, Laboratoire de Physiopathologie Moléculaire et Toxicologie, Department of Animal Physiology, Faculty of Science and Technology, University of Abomey-calavi 01 BP: 4521 Cotonou, University of Abomey-calavi, Benin, Tél: (+229) 97-55-21-25;E-mail: eattakpa@ yahoo.fr

\section{Abstract}

In the present study, we investigated the biochemical alterations and gene expression of carbohydrate and lipid metabolism after oral administration of Phyllanthus amarus. The quantitative estimation of total phenols, tannins and flavonoids showed that the extracts are rich in these compounds antioxidant potential of the ethanolic extract of the stem leaves of Phyllanthus amarus Schumach. \& Thonn. Was evaluated by using 1 , 1-diphenyl-2-picrylhydrazyl (DPPH) scavenging assay. The extract showed significant activities in all antioxidant assays compared to the reference antioxidant ascorbic acid in a dose dependent manner. Phyllanthus amarus significantly reduced the blood glucose level starting on the second week. Furthermore, the extract of $\mathrm{P}$ amarus showed significant increase in plasma insulin and tissue glycogen contents. The antidyslipidemic effect was demonstrated by a significant reduction in plasma total cholesterol (TC), triglycerides (TG), and low density lipoprotein-cholesterol (LDL-C), while the cardio-protective lipid, high density lipoprotein-cholesterol (HDL-C), was increased.

Phyllanthus amarus also modulated the activities of carbohydrate-metabolizing enzymes by significantly increasing the activity of hexokinase and pyruvate kinase $(\mathrm{p}<0.05)$ and significantly reducing the activity of glucose-6-phosphatase, fructose-1,6-diphosphatase and glycogen phosphorylase $(\mathrm{p}<0.05)$. Phyllanthus amarus administration up-regulated mrna expression of Glucose Transporter-2 (GLUT-2), and increased lipolysis and cholesterol metabolism through up-regulation of lipoprotein lipase (LPL), Sterol Responsible Element Binding Protein-1a (STREBP-1a) expression. FAS expression was down regulated. The Phyllanthus amarus induced increase in serum insulin level, glucokinase (GK), aldolase, pyruvate kinase (PK), succinate dehydrogenase (SDH), and glycogen synthase activities in addition to a higher expression of insulin receptor A (IRA), GK, SDH.

Keywords: P. amarus; Diabetes II; Gene expression ; Gene regulation ; Insulin ; Carbohydrate metabolic enzymes; lipid metabolism

\section{Introduction}

Plants have been and are still being processed and utilized as raw materials for pharmaceutical applications. Many of our modern drugs and processed scientific medicines are of plant origin [1]. Man has been using herbs for the treatment of many diseases. The plant Phyllanthus amarus belongs to the family Euphobiaceae and of the genus phyllanthus and the species is amarus [1].

Phyllanthus amarus Schumach. \& Thonn is from the branch of the Magnoliophyta and the large family of Euphorbiaceae, APG
2009. Euphorbiaceae is one of the largest plant families in the world (326 genus, 7750 species). P. Amarus is used traditionally to treat hepatitis [2]. Plants of the genus Phyllanthus are widely distributed in most tropical and subtropical countries and are generally used in traditional medicine to treat chronic liver disease [3]. Still called bitter Phyllanthus (French); Henlenwe (fon); Ashasha (yoruba, nagot); Sobaru (bariba); Banna banna biriku (dendi) [4], P. Amarus is an erect grass up to $50 \mathrm{~cm}$ tall, glabrous. The stem and leaves are light green; the flowers and fruits are small and hanging at the tips of the twigs. This species flowers and then fructifies between March and October. P. Amarus 
is a pan tropical species found in forest galleries, fallows, and roadside. This plant is used as a diuretic, astringent [5] also in the treatment of diabetes [6]. The phytochemical analysis of the P. Amarus extract confirmed the presence of tannins, saponins, flavonoids and alkaloids. The plant extract contains high levels of saponins, tannins, flavonoids and alkaloids $[7,8]$.

Diabetes mellitus is a chronic, hereditary disease characterized by an abnormally elevated level of blood glucose (hyperglycemia) and by the excretion of the excess of glucose in the urine (glycosuria). The basic defect appears to be an absolute or relative lack of insulin or decrease in insulin receptors on the membrane of the target cells, which lead to abnormalities in carbohydrate metabolism as well as in lipid and protein metabolism [9].

Diabetes mellitus, a serious chronic metabolic disorder, is identified by hyperglycemia resulting from deficiency in insulin secretion and/or decreased reaction of the organs to insulin [10, $11]$.

Diabetes mellitus has been and will probably continue to be classified as growth or juvenile onset and maturity or adult onset. In both the 1980 and 1985 reports, other classes of diabetes included other types [12]. The cause for type 1 diabetes is an absolute deficiency of insulin secretion, whereas type 2 diabetes is a combination of resistance to insulin action and inadequate compensatory insulin secretory response.

The world prevalence of diabetes among adults (aged 20 - 79 years) was 6.4\%, affecting 285 million adults, in 2010, and will increase to $7.7 \%$, and 439 million adults by 2030 [13].

Epidemiological studies have suggested that dyslipidaemia is a risk factor for diabetic neuropathy [14]. In diabetic subjects overproduction of FFA and impaired lipoprotein metabolism induces an increase in plasma lipid components [15]. Type 1 and Type 2 diabetes mellitus are associated with metabolic syndrome and a marked increase in the risk of coronary heart disease [16]. Adipose tissue is now recognized as an endocrine organ that contributes to the physiopathology of type 2 diabetes. Diabetes mellitus has also been associated with an increased risk for developing premature atherosclerosis due to an increase in triglycerides (TG) and low-density lipoproteins (LDL), and decrease in high density lipoprotein levels (HDL) [17].

Abnormalities of lipoprotein metabolism cause various hypoor hyperlipoproteinemias. The most common of these is diabetes mellitus, where insulin deficiency causes excessive mobilization of FFA and underutilization of chylomicrons and VLDL, leading to hypertriacylglycerolemia. Most other pathologic conditions affecting lipid transport are due primarily to inherited defects, some of which cause hypercholesterolemia, and premature atherosclerosis.

Obesity particularly abdominal obesity is a risk factor for increased mortality, hypertension, type 2 diabetes mellitus, hyperlipidemia, hyperglycemia, and various endocrine dysfunctions [18]. In addition to the established major risk factors, atherosclerosis in type 2 diabetes is also related to alterations in lipid and lipoprotein profile [19]. Many epidemiological studies have demonstrated that type 2 diabetes mellitus is a wellknown risk factor for the development of cardiovascular disease, cerebrovascular disease, and peripheral vascular diseases [20, 21].

Many of the drugs currently used in Diabetes mellitus (DM) are expensive and side effects are of serious concern [22]. Hence, natural products with perceived cost-effectiveness and no longterm side effects but which elicit better antidiabetic activities are highly desired. The health-promoting properties of some herbal teas or Chinese herbal medicines reported to be rich in antioxidants, particularly phenolics and antioxidant vitamins, can exert inhibitory capacities against $\alpha$-glucosidase and exert hypoglycemic effects [23, 24, 25].

A number of studies have shown that diabetes mellitus is associated with oxidative stress, leading to an increased production of reactive oxygen species. Antioxidant research is an important topic in the medical field as well as in the food industry. Recent research with important bioactive compounds in many plant and food materials have received much attention. The oxidation induced by ROS can result in cell membrane disintegration, membrane protein damage and DNA mutation, which can further initiate or propagate the development of many diseases, such as cancer, liver injury and cardiovascular disease [26].. Although the body possesses such defense mechanisms, as enzymes and antioxidant nutrients, which arrest the damaging properties of ROS [27]., continuous exposure to chemicals and contaminants may lead to an increase in the amount of free radicals in the body beyond its capacity to control them, and cause irreversible oxidative damage [28]. Therefore, antioxidants with free radical scavenging activities may have great relevance in the prevention and therapeutics of diseases in which oxidants or free radicals are implicated [29]. In this respect, polyphenolic compounds, like flavonoids and phenolic acids, commonly found in plants have been reported to have multiple biological effects, including antioxidant activity $[30,31,32,33]$. Currently, the possible toxicity of synthetic antioxidants has been criticized. It is generally assumed that frequent consumption of plantderived phytochemicals from vegetables, fruit, tea, and herbs may contribute to shift the balance toward an adequate antioxidant status [34]. Thus interest in natural antioxidant, especially of plant origin, has greatly increased in recent years [35].

The relationship between Phyllanthus amarus Schumach. $\&$ Thonn and streptozotocin-induced diabetic rats with regard to carbohydrate and lipid metabolism is not fully examined. Thus, this study was conducted to test the hypothesis that streptozotocin-induced diabetic rats induces systemic alteration in antioxidant activity and lipid profiles may be ameliorated by Phyllanthus amarus Schumach. \& Thonn. Administration through modulating expression of genes responsible for carbohydrate and lipid metabolism.

\section{Materials and Methods}

\section{Chemicals}

Streptozotocin (STZ) and all other chemicals were obtained from Sigma-Aldrich (St. Louis, MO, USA). 2,2-Diphenyl-2picrylhydrazyl (DPPH), potassium hexacyanoferrate $\left[\mathrm{K}_{3} \mathrm{Fe}(\mathrm{CN})_{6}\right]$, 
trichloroacetic acid, gallic acid, ascorbic acid, quercetin, and $\mathrm{Fecl}_{3}$ were purchased from Sigma Chemical ; Folin-Ciocalteu phenol reagent, anhydrous sodium carbonate $\left(\mathrm{Na}_{2} \mathrm{CO}_{3}\right)$, aluminium chloride, potassium acetate and solvent methanol were obtained from Merck Chemical Supplies (Darmstadt, Germany). All the chemicals used, were of analytical grade.

\section{Plant material}

The plant material was the ethanolic extract of the leafy stem powder of P. Amarus. The stem leaves were harvested at AbomeyCalavi department of Littoral (Bénin), in July 2016 and identified under the number AA $6715 / \mathrm{HNB}$ in the national herbarium of Benin.

\section{Preparation of ethanolic extract}

Two hundred and fifty grams (250 g) of dry powder of the leafy stem of P. Amarus were extracted by maceration with ethanol for $72 \mathrm{~h}$ stirring. Each extraction is repeated three times. Ethanol extract is recovered in each case after filtration using a paper filter; ethanol is eliminated from the filtrate by evaporation under reduced in a rota-evapour pressure. The obtained extracts were stored at $4^{\circ} \mathrm{C}$ until biological assay.

\section{Phytochemical screening}

Phytochemical screening of the plant was carried out according to the methods described by Wagner and Blat [36] and Brunet on [37] for the detection of plant secondary metabolites. Tanins, alkaloids, steroids, coumarins, saponins, naphthoquinones, triterpenes, lignans, pigments, anthracene derivatives, triterpenes, lignans, pigments, anthracene derivatives have been investigated using tube test. Each extract $(10 \mathrm{mg} / \mathrm{ml})$ were deposited on TLC plate to confirm the results. Each molecule family was then quantified after identification.

\section{Quantification of some bioactive molecules}

\section{Total phenolics content}

Total phenolics of each extract were estimated by Folinciocalteu reagent method [38]. This method is based on the reduction in alkaline media of phosphotungstic mixture (W042) phosphomolybdic (moo42-) of Folin reagent by the oxidizable group of phenolic compounds, leading to the formation of blue reduction products. Latter have a maximum absorption at 765 $\mathrm{nm}$ whose intensity is proportional to the amount of polyphenols present in the sample. Then, $200 \mu \mathrm{l}$ of diluted sample were added to $1 \mathrm{ml}$ of 1:10 diluted Folin-Ciocalteu reagent. After $4 \mathrm{~min}, 800$ $\mu \mathrm{l}$ of saturated sodium carbonate $(75 \mathrm{~g} / \mathrm{l})$ was added. After $2 \mathrm{~h}$ of incubation at room temperature, the absorbance at $765 \mathrm{~nm}$ was measured. The standard calibration curve was plotted using gallic acid $(y=0,043 x-0,051 ; R 2=0,994)$. The mean of three readings was used and the results expressed as mg of Gallic Acid Equivalents (GAE)/100 mg of extract.

\section{Total flavonoid content}

The determination of flavonoids was performed according to the colorimetric assay described previously [39]. To $1 \mathrm{ml}$ of extract $\left(100 \mu \mathrm{g} \mathrm{mL}^{-1}\right), 3 \mathrm{ml}$ of methanol, $0.2 \mathrm{ml}$ of $1 \mathrm{M}$ potassium acetate, $0.2 \mathrm{ml}$ of $10 \%$ aluminium chloride and $5.6 \mathrm{ml}$ of distilled water was added and left at room temperature for 30 minutes. Absorbance of the mixture was read at $415 \mathrm{~nm}$ using UV spectrophotometer. Quercetin was used as reference compound to produce the standard curve $(y=0,325 \mathrm{x}-0,363$; $\mathrm{R} 2=0,995)$ and the results were expressed as mg of quercetin equivalent (QE)/100 mg of extract.

Condensed tannins: Condensed tannins were estimated using the method of author [40] modified by author [41] Vanillin reagent was prepared by mixing equal volume: $8 \%$, methanol at $37 \%$ and $4 \%$ of vanillin in methanol. The mixture was maintained at $30^{\circ} \mathrm{C}$ before the assay. Two hundred (200) $\mu \mathrm{l}$ of each extract to be analyzed were added to $1000 \mu \mathrm{l}$ of reagent of vanillin; the mixture was stirred and incubated in darkness at $30{ }^{\circ} \mathrm{C}$ for $20 \mathrm{~min}$. The absorbance was measured at $500 \mathrm{~nm}$ by a spectrophotometer UV (Perkin Elmer) against white consisting of a mixture of methanol (37\%) and $\mathrm{HCl}(8 \%)$ with equal volume.

\section{DPPH radical scavenging activity}

The antioxidant activity was determined according to the method previously described [42]. In the presence of antioxidant which is typical for DPPH free radical decays, the change in absorbency at $517 \mathrm{~nm}$ is followed spectrophotometrically. Briefly, $1.5 \mathrm{ml}$ of a freshly prepared methanolic solution of DPPH (2\%) was mixed with $0.75 \mathrm{ml}$ of extract solution (1-0.007 mg/ml). After 15 min of incubation in the dark, at room temperature, absorbencies were read at $517 \mathrm{~nm}$ against a blank sample consisting of a 1.5 $\mathrm{ml}$ of methanol and $0.75 \mathrm{ml}$ of extract solution. All tests were performed in triplicate. DPPH radical inhibition percentage was calculated according to the following formula: inhibition (\%) $=[(\mathrm{AB}-\mathrm{As}) / \mathrm{AB}] \times 100$ were as is the sample (tested extract solution) absorbance and $\mathrm{AB}$ is the blank absorbance.

\section{Evaluation of Antihyperglycemic}

It has been done according to the method [43]. Six lots of five rats were constituted with a total of thirty (30) rats. All rats were beforehand submitted to a non-hydric fast for 16 hours before the experiment. Concentrations of $200 \mathrm{mg} / \mathrm{Kg}$ and $500 \mathrm{mg} / \mathrm{Kg}$ of ethanolic extract of the leafy stem powder of P. amarus. were administered to the lot 3 and lot 4 . Only distilled water with a dose of $10 \mathrm{ml} / \mathrm{Kg}$ was administered to the control. Lot 1 and lot 2 received each a dose of $5 \mathrm{ml} / \mathrm{Kg}$ of glibenclamid. Administration of D-glucose with a dose of $5 \mathrm{~g} / \mathrm{Kg}$ was done after a half of hour. The glycemias were taken with a SD CHECK glucometer in a sequential way every 30 minutes from start point corresponding to T0 up to 120 minutes corresponding to $\mathrm{T} 120$. Then a final measure was done at T180.

\section{Ethical notice}

The experimental protocol was approved by the Scientific Ethics Committee of the Doctoral School (Life Sciences) of the Faculty of Science and Technology (FAST) at the University of Abomey Calavi (UAC) under the number (UAC/FAST/ EDSV/1112107).

\section{Animals and diets}

Male Wistar rats, 2-3 months old and weighing 160-250 g, aged 9 to $12 \mathrm{w}$. After 1 week of acclimatization in the Laboratory 
of Physiopathologie Moléculaire et Toxicologie (Faculty of Science and Technology of the University of Abomey-Calavi), five lots of five rats were constituted with a total of thirty (30) rats. All rats were beforehand submitted to a non-hydric fast for 16 hours before the experiment. The rats were rendered diabetic by intraperitoneal (i.p.) Injection of streptozotocin $(40 \mathrm{mg} / \mathrm{kg}$ body weight) in $0.1 \mathrm{M}$ citrate buffer, ph 4.5. Concentrations of $200 \mathrm{mg} /$ $\mathrm{Kg}$ and $500 \mathrm{mg} / \mathrm{Kg}$ of ethanolic extract of Phyllanthus amarus Schumach. \& Thonn ( eet $(\mathrm{OH})$ P.a ) were administered to the lot 3 and lot 4 . Only distilled water with a dose of $10 \mathrm{ml} / \mathrm{Kg}$ was administered to the control.

The glycemias were taken with a SD CHECK glucometer. The extracts were administered in the morning for 21 days. The general guidelines for the care and use of laboratory animals, recommended by the Doctoral School (Life Sciences) of the Faculty of Science and Technology (FAST) at the University of Abomey Calavi (UAC) under the number (UAC/FAST/EDSV/1112107), were followed and the protocol was approved by the Regional Ethical Committee.

\section{Oral Glucose Tolerance Test (OGTT)}

Following three weeks of gavages with plant extracts, the rats were fasted overnight during $12 \mathrm{~h}$ before ogtt. The glycaemia test was performed before gavaging the rats with $3 \mathrm{~g} / \mathrm{kg}$ of glucose. The glycaemia was measured at different times till $120 \mathrm{~min}(0$, 30, 60, 90 and $120 \mathrm{~min})$.

\section{Biochemical assays}

On the last day of study, a complete blood sample was collected from the abdominal aorta after deep anesthesia and the plasma was isolated by centrifugation at $2500 \mathrm{rpm}$ for 5 $\min$ at $4^{\circ} \mathrm{C}$. Blood glucose levels were measured by the glucoseoxidase method using an Accu-chek blood glucose meter. Total cholesterol (TC), Triglyceride (TG), high-density lipoprotein (HDL)-cholesterol levels were measured in serum samples by using enzymatic method kits (Roche Diagnostics). The lipoprotein cholesterol sub-fractions in the serum, HDL, LDL, VLDL were estimated by precipitation with sodium phosphotungstatemagnesium chloride and sodium dodecyle sulphate reagents. The determination of insulin was performed in samples that were stored at $-80^{\circ} \mathrm{C}$. Serum insulin was determined using an ELISA kit (LINCO Research Inc, St. Charles, MO, USA), according to the manufacturer's instructions.

The fasting serum glucose measured by using commercially available kits (Agappe Diagnostics, Ernakulam, India). Activity of glycolytic enzymes was assayed: hexokinase was estimated by the method of Crane and Sols [44]; pyruvate kinase was estimated by the method of Bucher and Pfleiderer [45]. Hepatic glycogen content was estimated by the method of Carroll et al. [46]. Gluconeogenic enzyme activities in the liver were assayed using the following procedures: glucose-6-phosphatase was estimated by the method described by Koide and Oda [47], fructose-1,6diphosphatase was estimated by the method of Pontremoli [48], and the activity of glycogen phosphorylase was assayed by the procedure described by Singh et al. [49].
Other parts from the liver tissues were also frozen in on liquid nitrogen used for molecular analysis. One gram of each liver tissue samples were homogenized in $9 \mathrm{ml}$ of the homogenizing buffer at ph 7.4 for preparation of tissue homogenate.13 This homogenate was used to assay the activities of the hepatic enzymes. The hepatic glucokinase (GK) activity was determined by measuring the glucose-6-phosphate (G6P) formed by GK by formation of nicotinamide-adenine dinucleotide phosphate in the presence of glucose-6-phosphate dehydrogenase enzyme. The activity of succinate dehydrogenase (SDH) was measured by monitoring the reduction of 2, 6-dichlorophenolindophenol at $600 \mathrm{~nm} .14$ Hepatic aldolase activity was assayed by spectrophotometry at $340 \mathrm{~nm}$ using Aldolase Activity Colorimetric Assay kit (Biovision, Cat. No. K665-100, Milpitas, CA, USA), where one unit of aldolase activity is defined as the amount of enzyme that produced one $\mu$ mol of NADH per minute at $25^{\circ} \mathrm{C} .15$ Hepatic pyruvate kinase (PK) activity was determined in the liver homogenate with 50 $\mathrm{mm}$ glycylglycine, $15 \mathrm{~mm}$ ethylene diamine tetraacetic acid (EDTA), and $5 \mathrm{~mm}$ potassium phosphate. The total PK activity was determined in the supernatants as described.16 Glycogen synthase (GS) activity was measured in homogenates in the presence of $6.6 \mathrm{~mm} \mathrm{G6P}$, and the enzyme activity was expressed as $\mathrm{mu} / \mathrm{mg}$ protein.17 Hepatic glycogen content was determined as previously described.

Hepatic homogenate protein concentration was measured using a Bio-Rad assay reagent. Total RNA was extracted from the liver tissues using rneasy mini kit (Cat. No. 74104, Qiagen, China) following the manufacturer instructions. The amount of extracted RNA was quantified and qualified using nanodrop ND1000 Spectrophotometer (nanodrop Technologies, Wilmington, Delaware, USA). The purity of RNA was checked and it ranged between 1.8 and 2.1 demonstrating the high quality of the RNA. First strand cdna was produced using a specific kit that was supplied by Fermentas (Pittsburgh, PA, USA).

The polymerase chain reaction (PCR) was carried out by (2×) PCR Master Mix (Fermentas Inc., Pittsburgh, PA, USA). A 2720 thermocycler (Applied Biosystems, Foster City, CA, USA) was used in performing the PCR reactions. We used 10 pmol/ $\mu \mathrm{l}$ of each forward and reverse primer for the measured genes. The housekeeping gene $\beta$-actin was used as a constitutive control for normalization.. All primers were provided by Sigma Aldrich (Chemie gmbh, Steinheim, Germany) as shown in (Table 1). Amplified PCR products were analyzed on a 1.5\% agarose gel stained with ethidium bromide in $1 \mathrm{x}$ Tris acetate EDTA buffer (TAE) (ph: 8.3-8.5). The electrophoretic picture wasvisualized and analyzed by gel documentation system (Bio Doc Analyze, Biometra, Göttingen, Germany).

\section{Statistical Analysis}

The statistical analysis of the data was carried out in Predictive Analytics SoftWare Statistics for Windows version 18 (IBM SPSS Statistics, Endicott, New York, USA). One-way analysis of variance was used to determine the statistical differences between groups followed by Duncan's multiple range test to analyze the intergrouping homogeneity. Data were presented as mean \pm standard deviation. $\mathrm{P}<0.05$ was considered statistically significant. [23] 


\section{DPPH • + antioxidant $($ DPPH-H + antioxidant $\bullet$ \\ Purple color Yellow color}

Figure 1: DPPH radical was evaluated spectrophotometrically by following the reduction of this radical which is accompanied by its passage of the purple color (DPPH•) to the color yellow (DPPH-H) measurable to $517 \mathrm{~nm}$.

Table 1: PCR conditions for genes of carbohydrate and lipid metabolism

\begin{tabular}{|c|c|c|}
\hline mRNA expression & Forward primer & Reverse primer \\
\hline PK (229 bp) & 5'-ATTGCTGTGACTGGATCTGC-3' & 5'-CCCGCATGATGTTGGTATAG-3' \\
\hline PEPCK (236 bp) & 5'-TTTACTGGGAAGGCATCGAT-3' & 5'-TCGTAGACAAGGGGGCAC-3' \\
\hline GLUT-2 (330 bp) & 5'-AAGGATCAAAGCCATGTTGG-3' & 5'-GGAGACCTTCTGCTCAGTGG-3' \\
\hline SDH (249 bp) & 5'-TGGCTTTCACTTCTCTGTTGG-3' & 5'-ATCTCCAGTTGTCCTCTT CCA-3' \\
\hline FAS (345 bp) & 5'- CCAGAGCCCAGACAGAGAAG-3' & 5'-GACGCCAGTGTTCGTTCC-3' \\
\hline LPL (269 bp ) & 5'-CCTGATGACGCTGATTTTGT-3' & 5'-TATGCTTTGCTGGGGTTTTC-3' \\
\hline STREBP -1a (290 bp ) & 5'-ACACAGCGGTTTTGAACGACATC-3' & 5'-ACGGACGGGTACATCTTTACAG-3' \\
\hline INSULIN RECEPTOR A (222bp) & 5'-TTCATTCAGGAAGACCTTCGA-3' & 5'-AGGCCAGAGATGACAAGTGAC-3' \\
\hline BETA-ACTIN (309 bp) & 5'-TCACTATCGGCAATGTGCGG-3' & 5- GCTCAGGAGGAGCAATGATG-3' \\
\hline
\end{tabular}

PCR cycle of respective genes and annealing temperature are shown in the table, while temperature and time of denaturation and elongation steps of each PCR cycle are $94^{\circ} \mathrm{C}, 30 \mathrm{~s}$ and $72^{\circ} \mathrm{C}, 60 \mathrm{~s}$, respectively.

\section{Results}

\section{Phytochemical Screening}

Phytochemical Constituents extracts of ethanolic extract of the leafy stem powder of P. amarus. are shown in (Table 2). On the whole, coumarins, flavonoids, alkaloids, derivatives of anthracene, lignans, tannins and triterpenes were identified in extract. The ethanolic extract gave a positive result for all groups secondary metabolites investigate.

\begin{tabular}{|c|c|}
\hline Table 2: Phytochemical analysis of leafy stem powder of P. amarus. \\
\hline Chemical compound & Ethanolic extract \\
\hline Coumarin & + \\
\hline Flavonoid & + \\
\hline Naphtoquinone & + \\
\hline Alkaloid & + \\
\hline anthracene derivative & + \\
\hline saponin & + \\
\hline lignan & + \\
\hline triterpene & + \\
\hline Tanins & + \\
\hline triterpene & \\
\hline
\end{tabular}

\section{Quantification of some bioactive molecules family}

After the phytochemical screening, three chemical compounds groups such as total phenolic compounds, flavonoids and tannins were measured on the ethanolic extract. (Table 3) presented values obtained.
Table 3: Total phenolic compound, flavonoids and tannins content

\begin{tabular}{|c|c|c|c|}
\hline Ethanolic extract & $\begin{array}{c}\text { Total } \\
\text { Phenolic (a) } \\
\text { compound }\end{array}$ & Flavonoids $^{\text {(b) }}$ & $\begin{array}{c}\text { Condensed } \\
\text { tannins }^{\text {(c) }}\end{array}$ \\
\hline $\begin{array}{c}\text { Phyllanthus } \\
\text { amarus Schum. \& } \\
\text { Thonn. }\end{array}$ & $21,395 \pm 0,21$ & $11,815 \pm 0,118$ & $5,432 \pm 0,05$ \\
\hline $\begin{array}{l}{ }^{(a)} \text { mg equivalent of gallic acid/g of extract ; } \\
{ }^{(b)} \text { mg equivalent of rutin/g of extract; } \\
{ }^{(c)} \text { mg equivalent of catechin/mg of extract. }\end{array}$ \\
\hline
\end{tabular}

\section{Antioxidant activity DPPH Radical Scavenging Activity}

The DPPH (1,1-diphenyl-2-picrylhydrazyl) radical scavenging activity of Phyllanthus amarus Schumach. \& Thonn. is given in (Fig 2 ). This activity was increased by increasing the concentration of the sample extract. The reduction of DPPH radical by antioxidants is evaluated by the decrease in absorbance at $517 \mathrm{~nm}$. The decrease in absorbance of DPPH radical caused by antioxidants is due to the reaction between antioxidant molecules and radical progress which results in the scavenging of the radical by hydrogen donation [50]. It is visually noticeable as a change in colour from purple to yellow. Hence, DPPH is usually used as a substance to evaluate the antioxidant potential of medicinal plants [51]. In this study, the DPPH radical scavenging activities of extracts therefore increased gradually in a dose concentration dependent manner $(7.81-1000 \mu \mathrm{g} / \mathrm{ml})$. The results show that IC50 value of the extract was $0.042 \mathrm{mg} / \mathrm{ml}$, as opposed to that of ascorbic acid (IC50 0.010 $\mathrm{mg} / \mathrm{ml}$, IC50 $=$ Concentration inhibiting $50 \%$ of reaction), which is a well-known antioxidant. Total antioxidant activity was also found to increase in a dose dependent manner. 


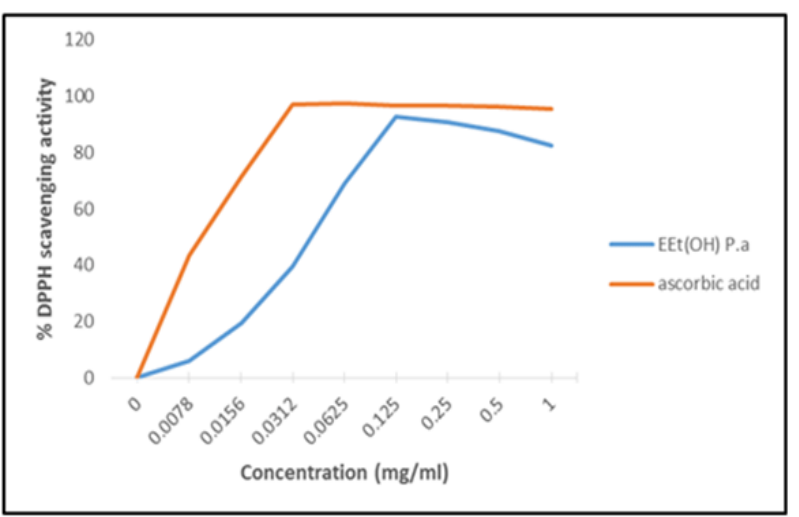

Figure 2: Radical scavenging activity of Antioxidant activity of Phyllanthus amarus Schumach. \& Thonn. EEt(OH) P.a: Ethanolic Extract of Phyllanthus amarus Schumach. \& Thonn.

Phyllanthus amarus Schumach. \& Thonn. extracts decrease hyperglycaemia (Fig. 3) shows that streptozotocin induced hyperglycaemia in rats. After gavaging the rats with extracts of Phyllanthus amarus., It is interesting to note that with the concentration of $200 \mathrm{mg} / \mathrm{kg}$ and $500 \mathrm{mg} / \mathrm{kg}$ significantly decreased the glucose levels dose-dependant during 3 weeks, i.e., from 7 th day to 21 st day of treatment. Hyperglycaemia in diabetic animals, suggesting that these extracts have hypoglycaemic effect. The extracts administered orally daily to rats were not toxic (results not shown).

Effect of repeated dose administration of P. amarus extract on oral glucose tolerance test in streptozotocin induced diabetic rats

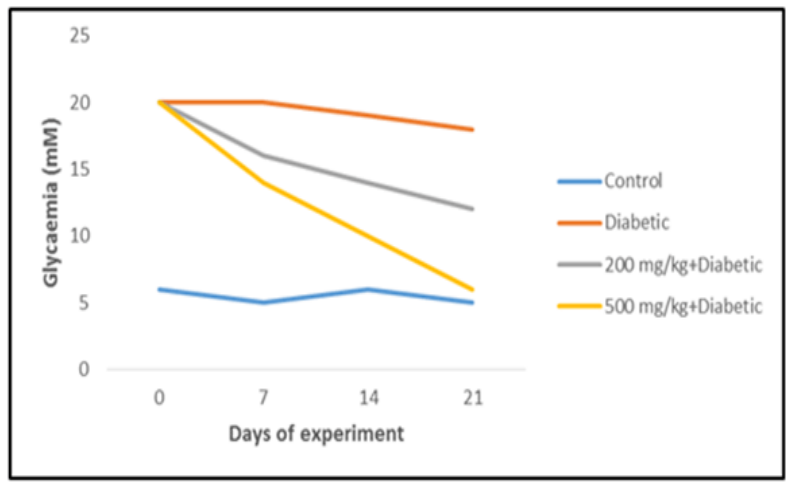

Figure 3: Blood glucose concentrations in control and diabetic rats, treated or not with extracts of Phyllanthus amarus Schumach. \& Thonn. for 3 weeks. Each value represents the mean $\pm \operatorname{SEM}(n=6)$.

The rats were also subjected to oral glucose tolerance test by gavaging $5 \mathrm{~g} / \mathrm{kg}$ of glucose. Blood glucose levels by OGTT in diabetic rats being administered different dosages of P. amarus extracts at day 21 are shown in (Fig 4). The oral glucose tolerance test-induced hyperglycaemia was higher in diabetic rats than control animals. The OGTT evoked hyperglycaemia is normalized after $2 \mathrm{~h}$ in control animals; however, the same phenomenon is decreased, but not normalized, in diabetic animals. It is interesting to note that the extracts from Phyllanthus amarus Schumach. \& Thonn. decreased rapidly hyperglycaemia in diabetic animals, suggesting that these extracts have hypoglycaemic effect, though the animals remained hyperglycemic as compared to control rats.

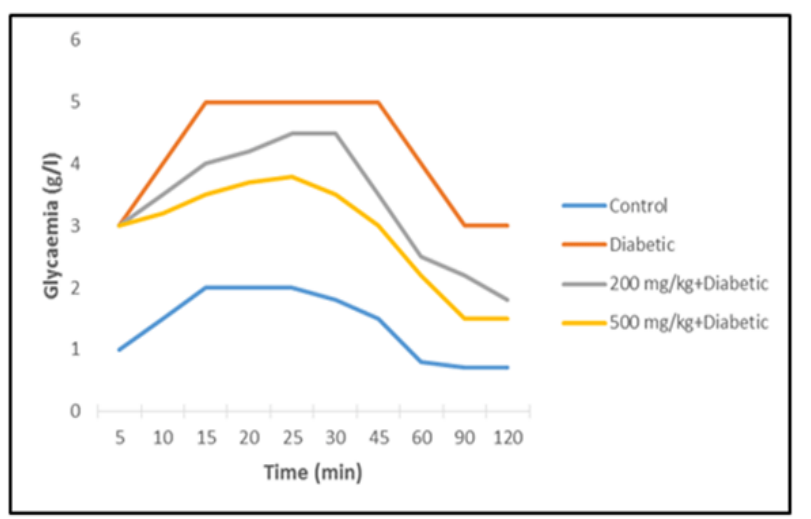

Figure 4: Oral glucose-tolerance test (OGTT) on day 21 in diabetic and control rats, treated or not with extracts of Phyllanthus amarus Schumach. \& Thonn. for 3 weeks. Glycaemia, during OGTT, was measured after a 15-h fasting, every 5-10 minutes, for 120 minutes following glucose administration as described in the Materials and Methods section. Each value represents the mean $\pm \operatorname{SEM}(n=6)$.

Effect of of P. amarus extract on plasma lipid profile Induction of obesity in Wistar rats increased serum levels of TAG, cholesterol, VLD and VLDL and decreased HDL levels. Administration of 200 $\mathrm{mg} / \mathrm{Kg}$ and $500 \mathrm{mg} / \mathrm{Kg}$ of ethanolic extract of the leafy stem powder of P. amarus normalized the increase in TAG, cholesterol, VLD and VLDL compared to control and diabetic rats. Regarding the changes in HDL levels, diabetic decreased HDL levels while both P. amarus administration normalized it relative to control and obese levels confirming their hypolipidemic action (Fig 5).

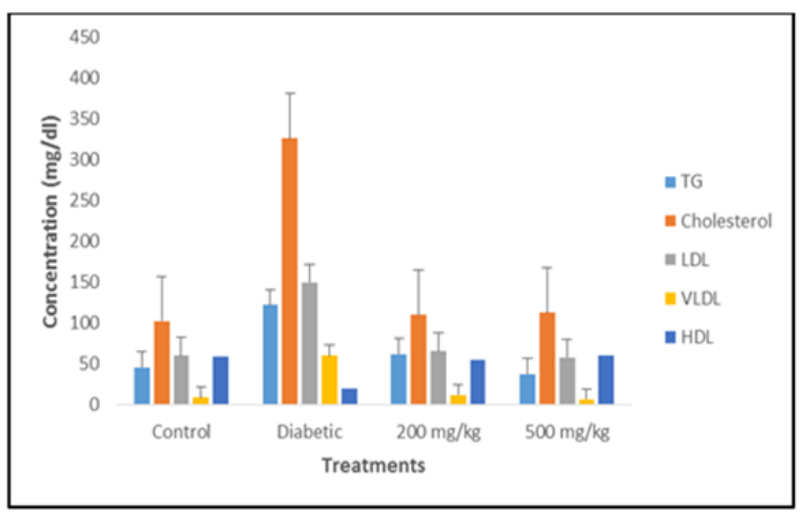

Figure 5: Anti-hyperlipidemic activities of Phyllanthus amarus Schumach. \& Thonn. on Strepto-zotocin-induced diabetics Wistar Rats. Each value represents the mean \pm SEM $(n=6)$.

Serum glucose, insulin levels and expression of insulin receptor A mRNA in streptozotocin-diabetic rats

The STZ induced diabetic group had low serum insulin levels. The STZ induced diabetic rats had significant decrease in the mRNA expression of hepatic insulin receptor A (IRA). While animals administrated with Phyllanthus amarus Schumach. \& Thonn showed a increase the levels of serum insulin (Fig 6 (a)) 
and hepatic IRA relative gene expression when compared with the diabetic rats (Fig 6 (b)). The Phyllanthus amarus Schumach. \& Thonn action was dose dependent where the highest effects observed in rats treated with a dose of $500 \mathrm{mg} / \mathrm{kg}$ bwt, and less effect with a low dose $200 \mathrm{mg} / \mathrm{kg}$ bwt. (a)

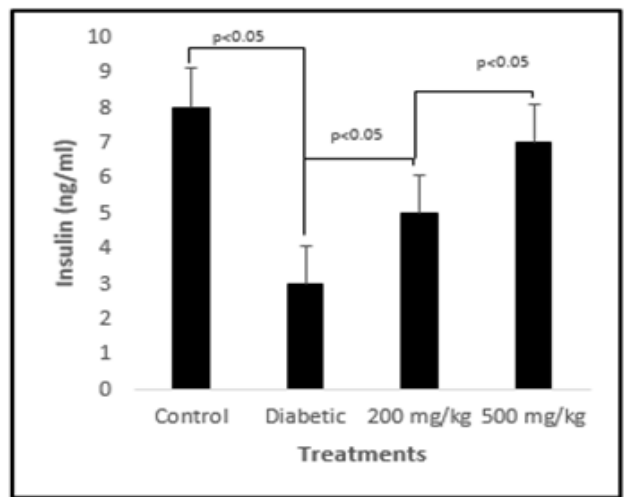

(b)

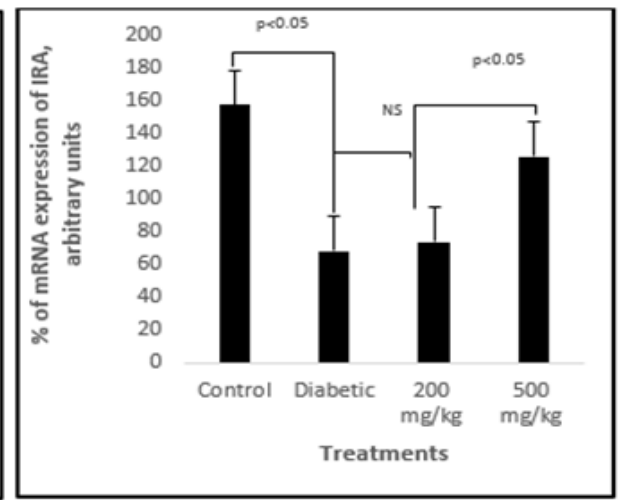

Figure 6: Serum insulin levels (a), expression of insulin receptor A mRNA (b). Each value is the mean of six determinations. Each value represents the mean \pm SEM $(n=6)$. Significant differences $(\mathrm{p}<0.05)$. NS=insignificant differences.

Effect of Phyllanthus amarus Schumach. \& Thonn extract on hepatic glycogen, carbohydrate enzyme activities and Lipid Metabolism in the liver in streptozotocin-induced diabetic wistar rats

Hepatic glycogen content in diabetic rats was found to be significantly reduced $(\mathrm{p}<0.05)$ compared with the normal control. Treatment with P. amarus enhanced the glycogen storage efficiency of liver of diabetic rats compared with diabetic control animals (Fig 7).

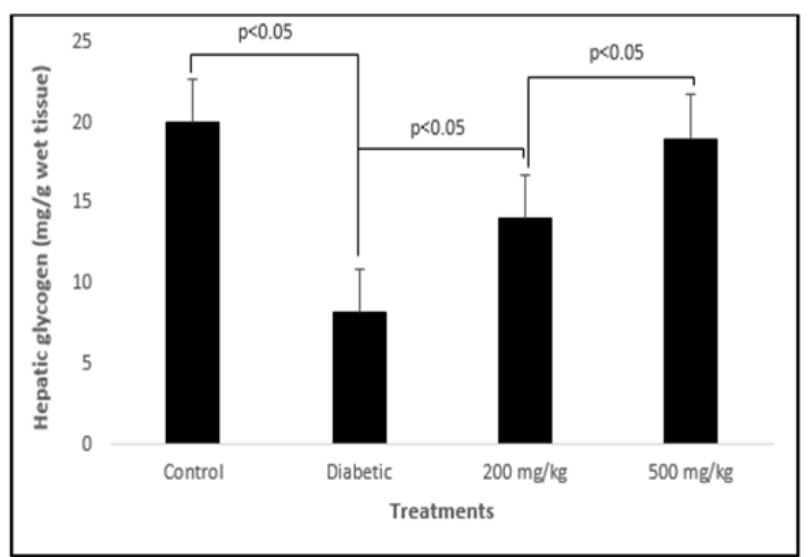

Figure 7: The activity of hepatic Glycogen in streptozotocin-diabetic rats. Each value is the mean of six determinations. Each value represents the mean \pm SEM $(n=6)$. Ssignificant differences $(p<0.05)$ between treatments.

STZ administration significantly $(\mathrm{p}<0.05)$ elevated the activity of glycogen phosphorylase in diabetic control rats as compared with the normal animals. Altered activity of the enzyme is reverted to near normal levels by extract administration in diabetic rats (Fig 8). No statistical significance between the extract-treated groups ( $>0.05$ ). The activities of pyruvate kinase (Fig 9) and hexokinase (Fig 10) were significantly diminished $(p<0.05)$ in STZ-induced diabetic rats as compared with normal control animals. However, P. amarus treatment significantly increased $(p<0.05)$ the activities of pyruvate kinase and hexokinase in liver tissues of diabetic rats.

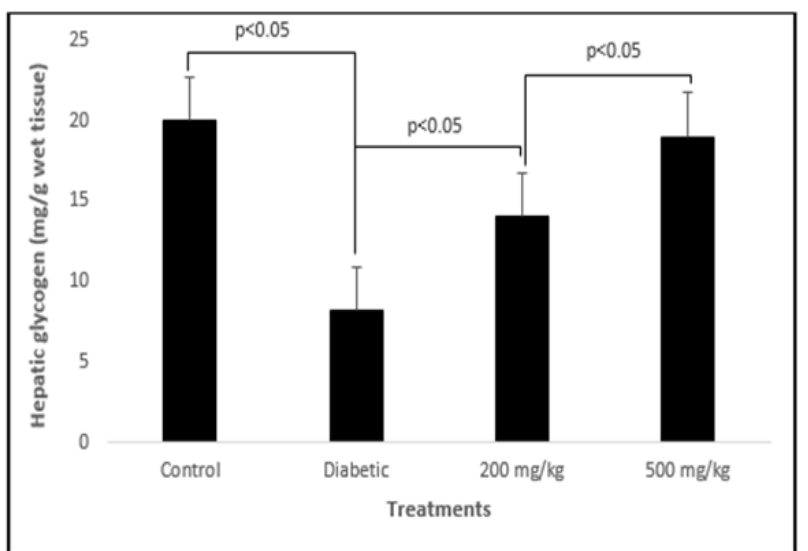

Figure 8: The activity of hepatic Glycogen Phosphorilase in streptozotocin-diabetic rats. Each value is the mean of six determinations. Each value represents the mean $\pm \operatorname{SEM}(\mathrm{n}=6)$. significant differences $(\mathrm{p}<0.05)$ between treatments. NS=insignificant differences

On the other hand, there was an increase in the activities of gluconeogenic enzymes like fructose-1,6-diphosphatase (Fig 11) and glucose-6-phosphatase (Fig 12) in diabetic rats as compared with the normal rats. Supplementation of P. amarus showed restoration of fructose-1,6-diphosphatase and glucose6-phosphatase $(\mathrm{p}<0.05)$ to the basal levels as compared with control rats. 
Activity of hepatic Pyruvate kinase

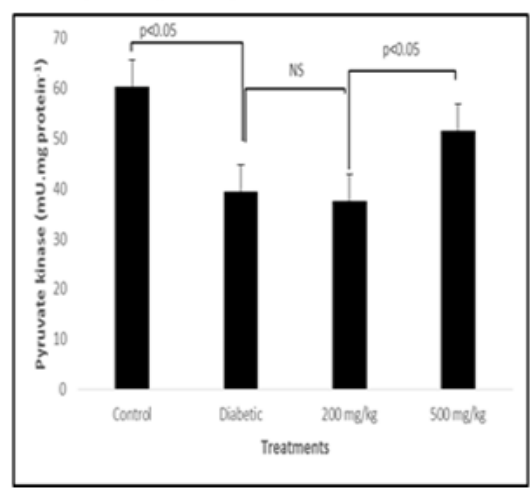

Relative gene expression of Pyruvate kinase

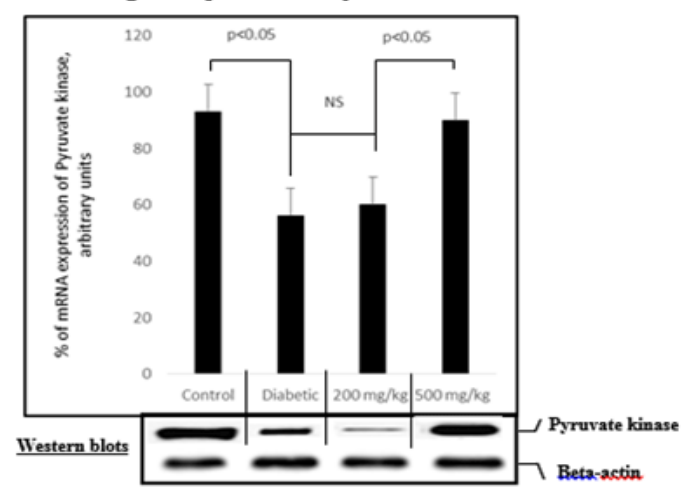

Figure 9: The activity of hepatic Pyruvate kinase and relative gene expression (relative to beta-actin gene expression) of Pyruvate kinase in streptozotocin-diabetic rats. Each value is the mean of six determinations. Each value represents the mean \pm SEM (n=6). significant differences ( $<<0.05)$. NS=insignificant differences.

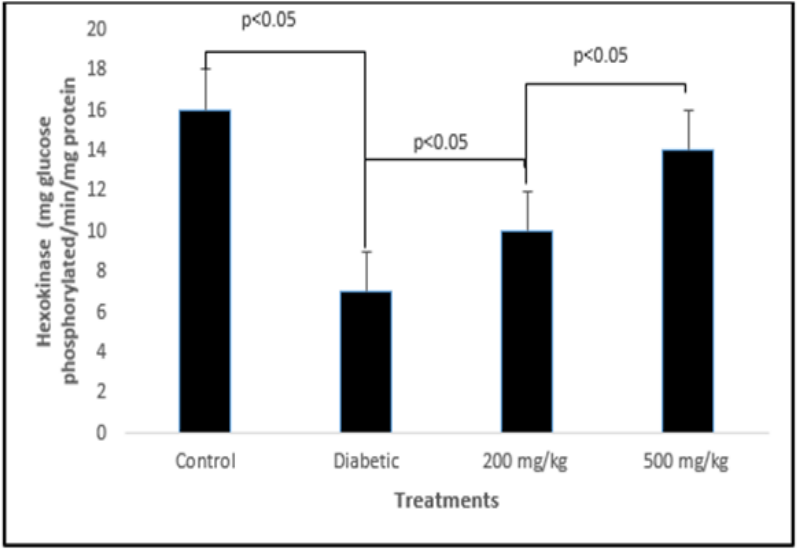

Figure 10: The activity of hepatic Hexokinase in streptozotocin-diabetic rats. Each value is the mean of six determinations. Each value represents the mean \pm SEM $(n=6)$. significant differences $(\mathrm{p}<0.05)$. NS=insignificant differences.

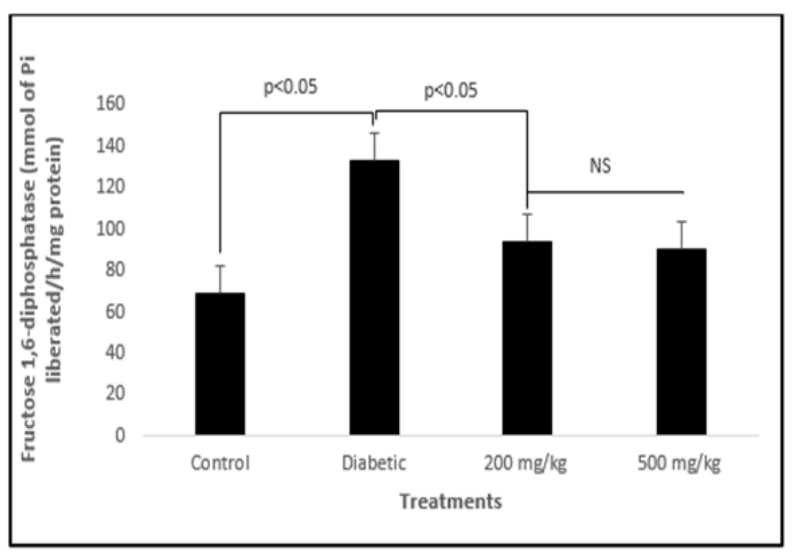

Figure 11: The activity of hepatic fructose-1,6-diphosphatasein streptozotocin-diabetic rats. Each value is the mean of six determinations. Each value represents the mean \pm SEM $(n=6)$. Significant differences $(p<0.05) . N S=$ insignificant differences.

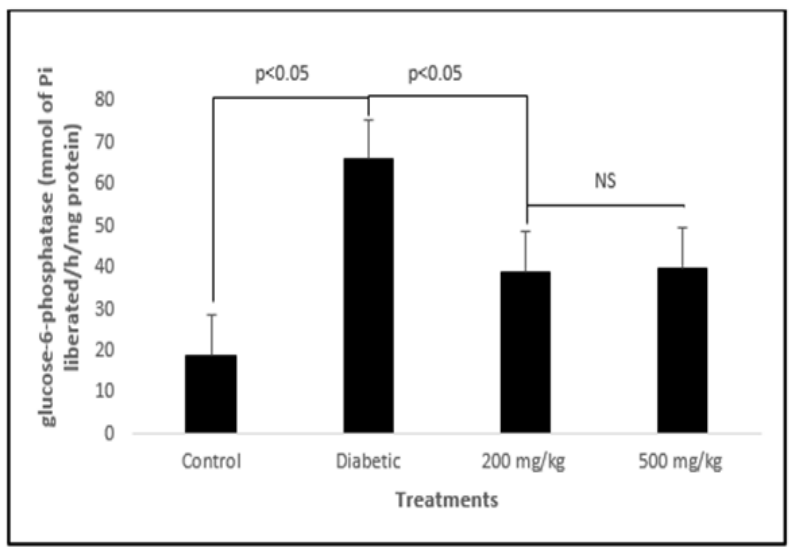

Figure 12: The activity of hepatic glucose-6-phosphatase streptozotocin-diabetic rats. Each value is the mean of six determinations. Each value represents the mean \pm SEM $(n=6)$. Significant differences $(p<0.05)$. $\mathrm{NS}=$ insignificant differences.

The expression of Glut-2 and phosphoenol pyruvate carboxykinase (PEPCK) were tested in liver tissue of the STZ induced diabetic rats and P. amarus-supplemented diabetic rats. As seen in (Fig 13 (a)), an increase in GLUT-2 mRNA expression (Figure 13(a)) was recorded. Any significant changes in mRNA expression of PEPCK (Figure 13(b)).

The STZ induced diabetic rats had significant decrease in the levels of GK, SDH relative gene expression compared with control rats $(\mathrm{p}<0.05)$. While animals administered with P. amarus showed an increase in the levels of hepatic, GK, SDH relative gene expression when compared with the diabetic rats (Fig 14, 15). While animals administrated with P. amarus induced the activities of hepatic aldolase, and GS, when compared with the diabetic rats (Fig 16, 17). The P. amarus action was dose dependent where the highest effects observed in rats treated with a dose of $500 \mathrm{mg} / \mathrm{kg}$ bwt, and less effect with a low dose $200 \mathrm{mg} / \mathrm{kg}$ bwt. 
(a)

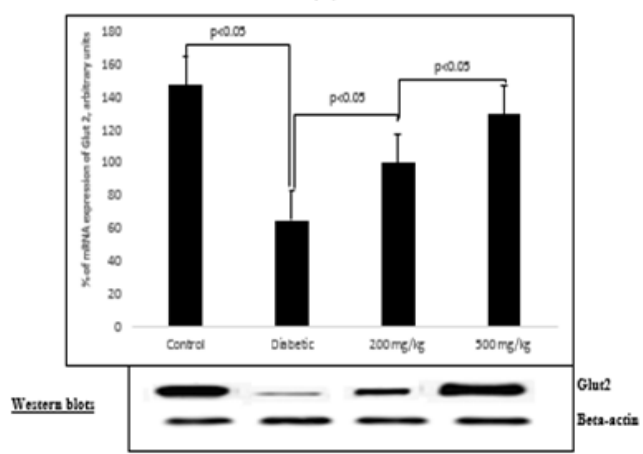

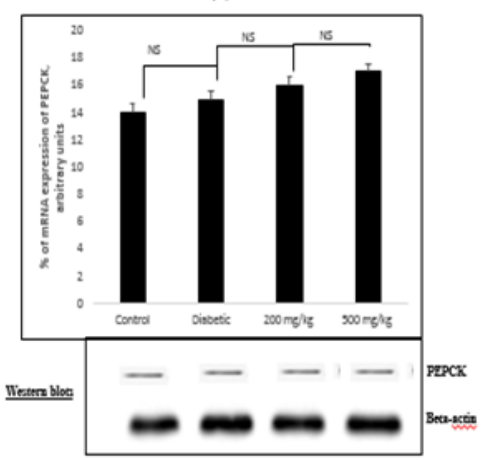

Figure 13: RT-PCR analysis of Glut-2 (a) and PEPCK (b) expression after oral administration of Phyllanthus amarus for 21 days to the STZ induced diabetic group Wistar rats as described in materials and methods. RNA was extracted and reverse transcribed $(1 \mu \mathrm{g})$ and RT-PCR analysis was carried out for Glut-2 and PEPCK genes. Densitometric analysis was carried for 6 different rats. Each value represents the mean \pm SEM $(n=6)$. significant differences $(\mathrm{p}<0.05)$. NS=insignificant differences.

Activity of hepatic GK

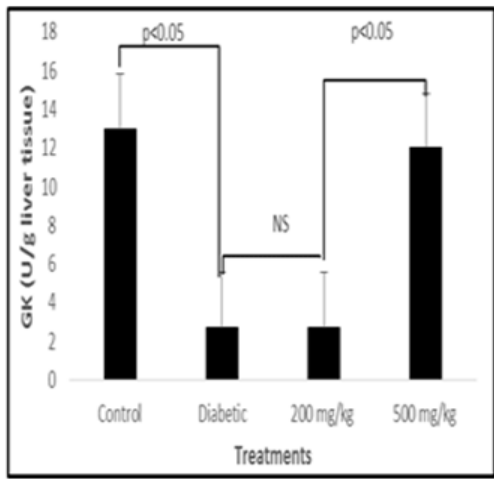

Relative gene expression of glucokinase (GK)

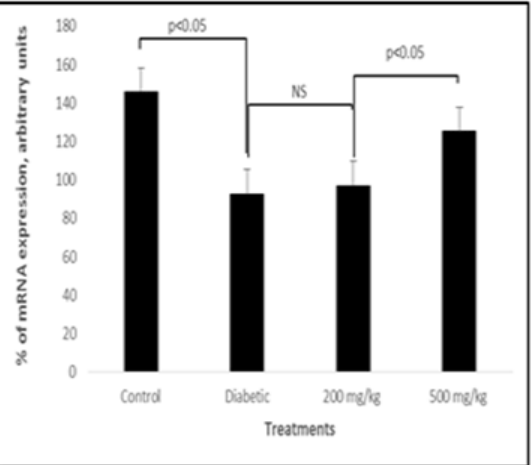

Figure 14: RThe activity of hepatic GK and relative gene expression of glucokinase in streptozotocin-diabetic rats. Each value is the mean of six determinations. Each value represents the mean \pm SEM $(n=6)$. significant differences $(p<0.05)$. NS=insignificant differences

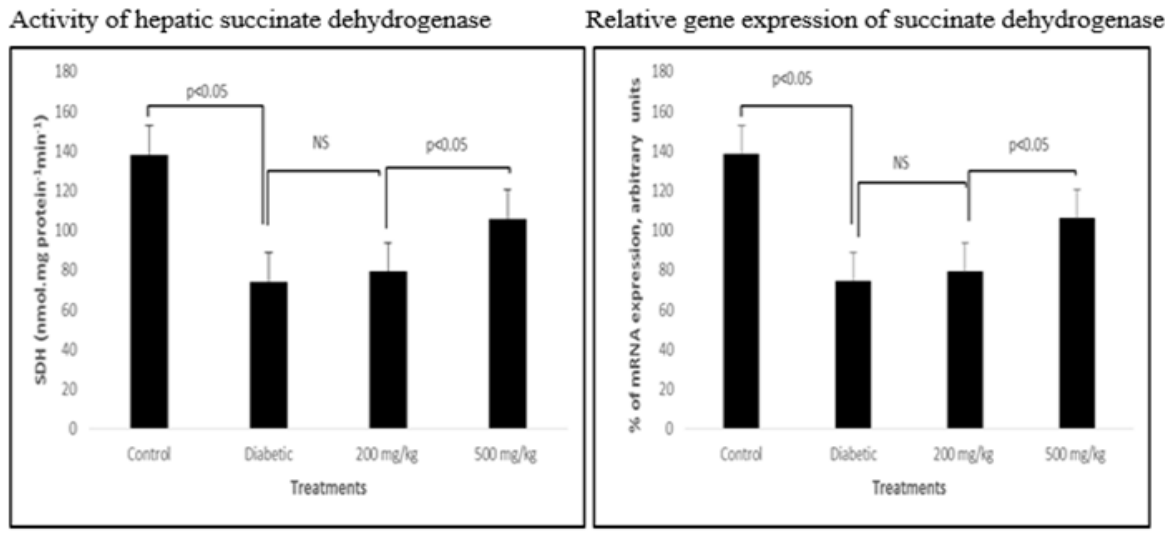

Figure 15: The activity of hepatic succinate dehydrogenase (SDH) and relative gene expression of succinate dehydrogenase in streptozotocin-diabetic rats. Each value is the mean of six determinations. Each value represents the mean $\pm S E M(n=6)$. significant differences $(p<0.05)$. NS=insignificant differences 


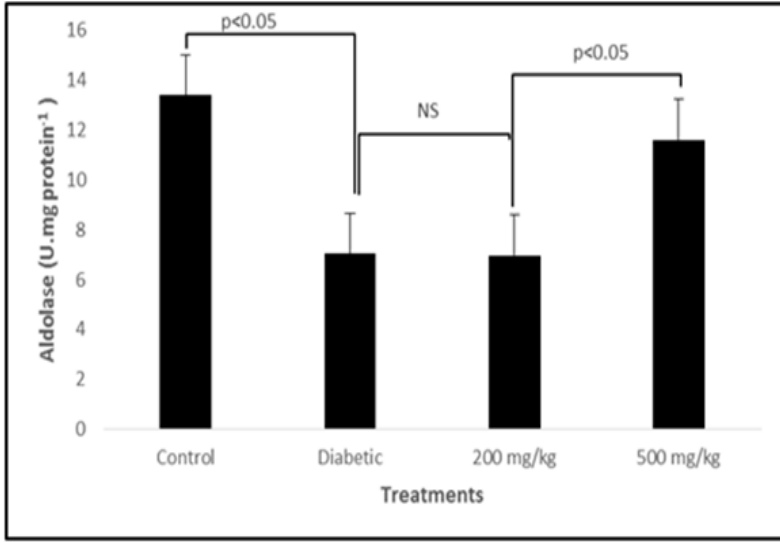

Figure 16: The activity of hepatic aldolase, in streptozotocin-diabetic rats. Each value is the mean of six determinations. Each value represents the mean $\pm \operatorname{SEM}(n=6)$. significant differences $(\mathrm{p}<0.05)$.

Effect of Phyllanthus amarus Schumach. \& Thonn extract on Lipid Metabolism in streptozotocin-induced diabetic wistar rats Moreover, 200 and $500 \mathrm{mg} / \mathrm{kg}$ b.w. Phyllanthus amarus Schumach. \& Thonn. extracts modulated lipid metabolism (Fig 18) as they increased lipolysis by upregulation of LPL mRNA expression (Fig 18 (a)). Finally, $200 \mathrm{mg} / \mathrm{kg}$ b.w. and $500 \mathrm{mg} / \mathrm{kg}$

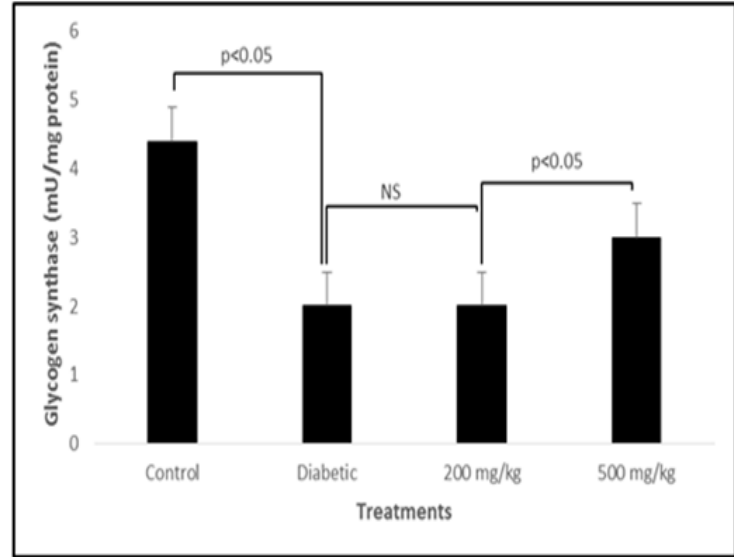

Figure 17: The activity of Glycogen synthase in streptozotocin-diabetic rats. Each value is the mean of six determinations. Each value represents the mean $\pm \operatorname{SEM}(n=6)$. significant differences $(\mathrm{p}<0.05)$.

b.w up-regulation in mRNA expression of STREBP-1a genes that are essential for hepatic cholesterol metabolism (Fig 18 (b)). Regarding their effects on FAS, the results showed that $200 \mathrm{mg} /$ $\mathrm{kg}$ b.w. is less effective on FAS mRNA expression than $500 \mathrm{mg} / \mathrm{kg}$ b.w (Figure 18 (c)). (a)

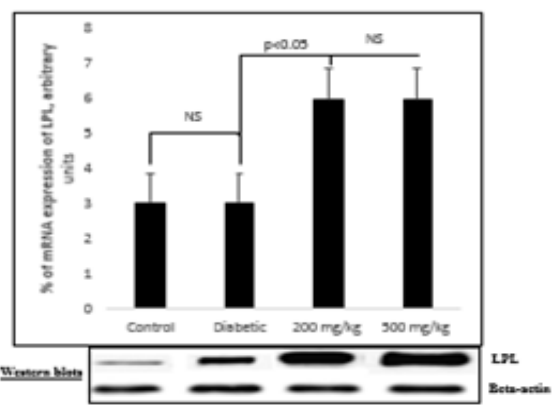

(b)

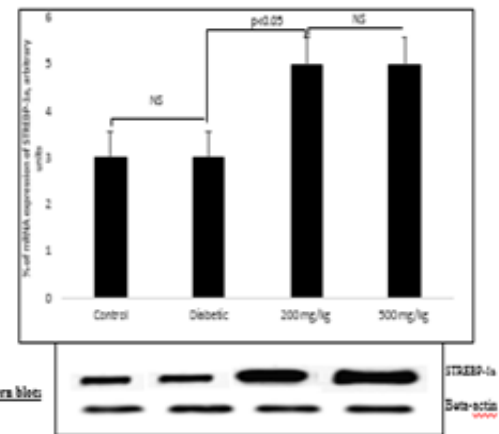

(c)

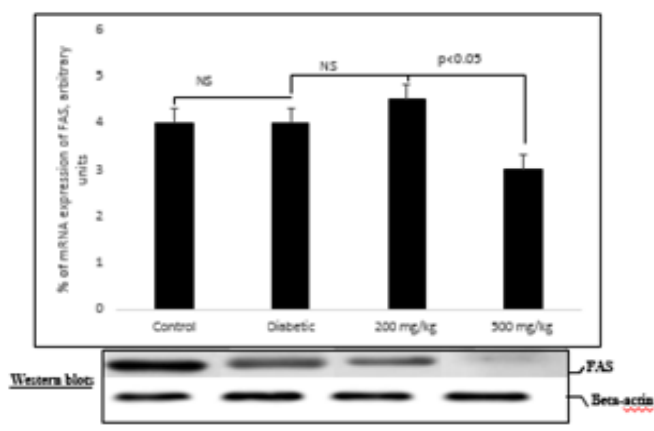

Figure 18: RT-PCR analysis of LPL (a), STREBP -1a (b), and FAS (c) expression after oral administration of Phyllanthus amarus for 21 days to the STZ induced diabetic group Wistar rats as described in materials and methods. RNA was extracted and reverse transcribed ( $1 \mu \mathrm{g})$ and RT-PCR analysis was carried out for LPL, SREBP-1a, and FAS genes. Densitometric analysis was carried for 6 different rats. Each value represents the mean \pm SEM ( $\mathrm{n}=6$ ). Significant differences $(\mathrm{p}<0.05)$. NS=insignificant differences. 


\section{Discussion}

The result for the phytochemical screening of P. Amarus as shown in (Table 1) revealed the presence of Coumarin, Flavonoid, Naphtoquinone, Alkaloid, anthracene derivative, saponin, lignan, triterpene, Tanins. From these results, the level of detection of these components depended on the method of preparation of the sample, solvent used and the temperature. The components detected have been shown to exhibit various therapeutic properties such as the astringent action of tannins, anti-inflammatory and anti-allergic effect of flavonoids. Some carbohydrate, flavoniods, steroids and alkaloids have been shown to exhibit anti-diabetic action [1], [52], [53]. The detection of most of these plant constituents in P. Amarus have suggested the possibility of using the plant in the treatment and management of many aliments including non-insulin dependent diabetes mellitus [54], [55]. Saponins inhibit sodium efflux by blocking the entrance of the sodium ions into the cell [56], hence activating sodium-calcium antiporter producing elevated cytosolic calcium which strengthens the contractions of heart muscle and thus reducing congestive heart failure.

The main goal of this study is to determine the free radical scavenging properties screened for in vitro plant extraction of Phyllanthus amarus Schum. \& Thonn. Free radical scavenging activity was evaluated using 1,1-diphenyl-2-picrylhydrazyl (DPPH) method. The result of the present study showed that the ethanol extract of Phyllanthus amarus Schum. \& Thonn., contains highest amount of phenolic compounds. Phenolic compounds are known as high-level antioxidants because of their ability to scavenge free radicals and active oxygen species, such as singlet oxygen, superoxide free radicals and hydroxyl radicals [57]. The radical-scavenging activity is attributed to replacement of hydroxyl groups in the aromatic ring systems of the phenolic compounds as a result of their hydrogen donating ability [58].

The possible mechanism of the extract may in part be attributed to its antioxidant activities. Complementing our findings, earlier studies have reported that the extract may have antioxidant activity. Phyllanthus amarus have been reported to be rich in phenolic compounds (Martin-Nizard et al. 2003) and these compounds were previously served as free radical scavengers [59]. Hyperglycemia generates reactive oxygen species (ROS), which in turn cause lipid peroxidation and membrane damage [60].

The possible mechanism of the extract may in part be attributed to its antioxidant activities. Complementing our findings, earlier studies have reported that the extract may have antioxidant activity. Phyllanthus amarus have been reported to be rich in phenolic compounds [61] and these compounds were previously served as free radical scavengers [59]. Hyperglycemia generates reactive oxygen species (ROS), which in turn cause lipid peroxidation and membrane damage [60].

The experimentally induced diabetic rats showed severe hyperglycemia interrelated with a decrease in endogenous insulin secretion and release. Rats treated with Phyllanthus amarus extract showed a significant decrease in the level of blood glucose and an increase in the level of serum insulin. These results indicated that Phyllanthus amarus produced anti-hyperglycemic activity and the glucose-lowering activity of Phyllanthus amarus may be attributed to pancreatic-enhancement of insulin secretion. Increment in plasma insulin by Phyllanthus amarus is probably due to the presence of derivatives which possess insulin secretagogue activity. It may also be due to the regeneration of pancreatic b cells which are destroyed by STZ [62].

According to previous reports, Diabetes mellitus (DM) was presented with alterations in glucose homeostasis that contribute to persistent hyperglycemia and liver plays a major role in the regulation of glucose metabolism [63]. The experimentally induced diabetic rats showed severe hyperglycemia interrelated with a decrease in endogenous insulin secretion and release. Rats treated with Phyllanthus amarus extract showed a significant decrease in the level of blood glucose and an increase in the level of serum insulin.

The phytochemical screening of Phyllanthus amarus showed the presence of constituents which were characterized and identified for the first time in this work and were having medicinal properties such as antioxidant [64]. Anti-inflammatory [65], anticancer [66], and hypoglycemic activities [67]. Hypoglycaemic effect of Egyptian Morus alba root bark extract: Effect on diabetes and lipid. The antidiabetic activity of Phyllanthus amarus may be attributed to the cumulative effect of these major compounds present in it.

Oral glucose tolerance test (OGTT) outcomes from the present study could lead us to believe that Phyllanthus amarus Schum. \& Thonn. May repair pancreas beta cells and enhance insulin secretion that then decrease blood glucose levels. Furthermore, treatment with Phyllanthus amarus Schum. \& Thonn. Improves glucose tolerance in diabetic rats, suggesting an enhanced insulin secretion. The ogttevoked hyperglycaemia is normalized after $2 \mathrm{~h}$ in control animals; however, the same phenomenon is decreased, but not normalized, in diabetic animals.

This study was designed to investigate the effect of the oral administration of Phyllanthus amarus Schum. \& Thonn. Extract on plasma glucose, triglycerides, LDL, HDL, VLDL total cholesterol levels in normal and diabetic rats.

Our results show that Phyllanthus amarus Schum. \& Thonn. Administration could decrease triglycerides, cholesterol, VLDL and LDL cholesterol and also increase HDL cholesterol. The decrease in serum triglycerides may be associated with the change in total serum Mg concentration. There is increasing evidence for the role of magnesium in the modulation of serum lipids and lipid uptake in macrophages [68].

Our hypothesis is Phyllanthus amarus induces insulin production and tissues insulin sensitivity, leading to an increase in the tissues glucose uptake, storage, and oxidation. In this study, we demonstrated the anti-hyperglycemic action of Phyllanthus amarus in STZ-induced diabetic rats. It decreased the blood glucose level in male STZ-induced diabetic rats particularly with the high dose $(500 \mathrm{mg} / \mathrm{kg}$ bwt). The anti-hyperglycemic effect of Phyllanthus amarus was dose dependent. The Phyllanthus amarus extracts decreased the serum glucose levels in diabetic 
rats. The anti- hyperglycemic effect of Phyllanthus amarus might be exerted by increasing insulin synthesis, and release by the beta cells of the islet of Langerhans and inducing the sensitivity of cell receptors to insulin. This appears through the induction of expression of the insulin gene in pancreatic cells and IRA in hepatic cells, and increasing the serum insulin levels consequently increased glucose uptake through induction of Glut 2 gene expression. The hypoglycemic effect of Phyllanthus amarus was exerted through potentiation of insulin synthesis and release from the existing beta cells, as well as increasing the tissues sensitivity of insulin to glucose uptake [69].

The STZ induces a selective destruction of pancreatic $\beta$-cells leading to poor glucose utilization inducing hyperglycemia, but leaving many of the surviving beta cells, which can be regenerated [70]. Such regeneration is enhanced by the administration of Phyllanthus amarus, and results in stimulating insulin release through increasing the level of gene expression, and so increasing its level in the blood, which can improve glucose metabolism.

Insulin receptors are expressed with different ranges in all tissues that are sensitive to insulin [71].This enforce our results, which showed high hepatic IRA gene expression levels in the groups that were administrated high doses of Phyllanthus amarus. That possess hypoglycemic, as well as antioxidant properties. Some flavonoids have hypoglycemic properties because they improve altered glucose and oxidative metabolisms of the diabetic states. They also exert a stimulatory effect on insulin secretion by changing $\mathrm{Ca}++$ concentration [72].

The activity of enzymes like hexokinase, pyruvate kinase, glucose-6-phosphatase, and fructose-1,6-diphosphatase was markedly altered, resulting in hyperglycemia, which leads to the pathogenesis of diabetic complications [73]. The altered the activity of hexokinase and pyruvate kinase, key enzymes in the catabolism of glucose, diminishing the metabolism of glucose and ATP production in diabetic conditions. The reduction in the activities of these enzymes in the liver tissues of diabetic rats is an indication of reduced glycolysis and amplified gluconeogenesis signifying that these two pathways are distorted in diabetes. In agreement with the above reports, the activities of hexokinase and pyruvate kinase were significantly decreased in the STZinduced DM group. The PK is a glycolytic enzyme playing a central role in hepatic glucose and lipid metabolism. It is regulated by phosphorylation, allosteric modification, hormones, and nutrients. Excess glucose utilization by tissue induces glycolysis, L-Pyruvate kinase (L-PK) activity, glycogenesis, de novo-synthesis of fatty acids, and lipid storage. The L-PK gene transcription is induced by insulin stimulated glucose metabolism [74]. Treatment with $200 \mathrm{mg} / \mathrm{kg}$ and $500 \mathrm{mg} / \mathrm{kg}$ bwt of Phyllanthus amarus causes an increase in the serum insulin level $(\mathrm{p}<0.05)$. The elevation in the serum insulin could result in activation of L-PK gene expression, and the enzyme activity that presented in our results, which refer to increase in the glycolytic pathway by treatment with 200 and $500 \mathrm{mg} / \mathrm{kg}$ bwt of Phyllanthus amarus, whereas treatment with $200 \mathrm{mg} / \mathrm{kg}$ bwt failed to produce this effect. The PK activity decreases as the result of diabetes and increases by the administration of insulin to diabetic rats in the liver tissues [75]. The increase in activity of PK in the liver tissue of rats is the cause of the increase in glycolysis and the decrease in gluconeogenesis as indicated by PEPCK mrna expression [76].

Administration of Phyllanthus amarus to diabetic rats significantly elevated these enzyme activities in liver. The activities of regulatory enzymes in gluconeogenesis, like glucose6-phosphatase and fructose-1,6-diphosphatase, are elevated in Diabetes mellitus [77] and increased activities of these enzymes in STZ-induced diabetic rats may be due to insulin insufficiency [78]. Glucose-6-phosphatase and fructose-1,6-diphosphatase are dephosphorylating enzymes which impair hepatic glucose utilization. Our results showed that the activities of glucose-6phosphatase and fructose-1,6-diphosphatase were significantly decreased by the administration of Phyllanthus amarus. Glycogen is the primary intracellular storage form of glucose and its quantity in various tissues is a direct manifestation of insulin activity as insulin supports intracellular glycogen deposition [79]. The reduced glycogen store in diabetic rats has been attributed to the loss of glycogen synthase-activating system and/or the increased activity of glycogen phosphorylase [80]. In the present study, there was a decrease in the hepatic glycogen content of diabetic rats which suggests the increased glucose output during insulin deficiency. Here diabetic animals showed increased glycogen phosphorylase activity when compared with normal control animals. Treatment with Phyllanthus amarus restored the levels of glycogen, probably by means of decreasing the activity of glycogen phosphorylase.

Hepatic glucose utilization was induced possibly due to the induction of gene expression of the Glut 2 gene.

The latter is a membrane bound glucose transporter present mainly in the liver, and not dependent on insulin. It has a high glucose Michaelis constant $(\mathrm{Km})$ and so the transporting of glucose into hepatic tissue is unlimited [81]. Glucose that is transported to the liver is either oxidized, or stored as glycogen. The Phyllanthus amarus improved the activity and gene expression of hepatic glucose catabolic enzymes GK, aldolase and SDH in harmony by increasing the level of gene expression of insulin gene and serum insulin levels. The GK activity and gene expression was increased in the Phyllanthus amarus treated rats when compared with diabetic non-treated rats.

The gene expression of GK is correlated with enzyme activity. The GK enzyme catalyzes the first hepatic glycolysis reaction, it has a low blood glucose affinity with high $\mathrm{Km}$. So it has a high sensitivity to blood glucose level change [81]. The GK activity and expression levels are decreased in diabetic patients [82]. The GK is a strong diabetic therapy marker because it enhances the hepatic glucose uptake and insulin secretion from pancreatic tissue [83]. Aldolase is a bi-functional enzyme in both glycolysis and gluconeogenesis; it is closely related to PFK-1 (phosphofructokinase-1) in its action as it cleaves its product (F1, 6 bisphosphate) into glyceraldhyde-3-phosphate and dihydroxy acetone phosphate. Its level was reported lower in the diabetic models [84], the increase in its activity after Phyllanthus amarus treatment may refer to improvement of glucose oxidation. The SDH is an oxidative mitochondrial enzyme that controls transcription of metabolism-related genes in mitochondria, 
and promotes glucose and lipid metabolism. The SDH mrna expression levels were reduced in diabetic animals [85]. Our study showed that treatment with 200 and $500 \mathrm{mg} / \mathrm{kg}$ bwt of Phyllanthus amarus can increase the SDH mrna levels and activity that improves the oxidative status in diabetic rats [86] Glycogenesis is another pathway for glucose utilization in the liver that is directly affected by insulin; the decrease in insulin level in diabetic rats results in the decrease of GS activity, and so decrease in liver glycogen content [87]. Such decrease in the activity was reversed by Phyllanthus amarus treatment with doses of 200 and $500 \mathrm{mg} / \mathrm{kg}$ bwt by the correction of insulin level in the blood. The hypoglycemic action of Phyllanthus amarus was accompanied by the activation of GS, and increases the hepatic glycogen content [88]. The STZ induces a selective destruction of pancreatic $\beta$-cells, which may be regenerated giving false results.

It could be predicted that glycogen levels in tissues (muscle and liver) decreased as the influx of glucose in liver, thus, inhibited in the absence of insulin and recovered on insulin treatment [89]. Our findings showed that the administration of Phyllanthus amarus to streptozotocin-induced diabetic wistar rats significant increase in PK mrna expression without changes in PEPCK mrna expression. Moreover, Glut 2 expression increased after Phyllanthus amarus administration. As known Glut 2 is a trans-membrane carrier protein, which enables passive glucose movement across cell membranes. Glut 2 is the principal transporter for the transfer of glucose between liver and blood, and for renal glucose reabsorption [90].

Elevated TG, cholesterol and LDL levels, and reduced HDL are the key abnormalities that constitute dyslipidemia [91] Here, our results show that Phyllanthus amarus administration normalized the changes induced in lipid profiles suggesting an improvement in insulin sensitivity through up-regulation in LPL, STREBP-1a expression, while FAS expression was down regulated. All together shows the importance of Phyllanthus amarus as nutrient molecules which help in preventing the changes in lipid profiles and regulated the gene expression of carbohydrate, lipid metabolism and with their antioxidant activities in streptozotocin-induced diabetic rats.

\section{Conclusion}

In conclusion, the Phyllanthus amarus has both a hypoglycemic effect and an antidyslipidemic activity. The possible mechanism of the anti diabetic action may be through a stimulation of insulin release from the remnant pancreatic b-cells. Both anti diabetic and anti dyslipidemic effects may in part be due to its antioxidant activity. It can also decrease vessel atherosclerosis and prevent diabetic vessel complications. In our view, it appears that Phyllanthus amarus administration may decrease cardiovascular risk factors.

Our results support the hypothesis that Phyllanthus amarus has a potential role in the management of diabetes and in the prevention of some complications in STZ-induced diabetic rats and that it may be useful in the treatment of hyperlipidemia in diabetes. Further studies will be needed to confirm the role of Phyllanthus amarus in lipid metabolism control.

\section{Acknowledgement}

We highly appreciate the contribution of Professor Naim Akhtar Khan who established the collaborative between Dijon (France), and Cotonou (Benin).

\section{References}

1. Trease GE \& Evans. WC Text book of Pharmacognosy.14th Ed. WB Saunders Company Limited; U.K: 2001.

2. Tássia Campos de Lima e Silva, Jorge Veras Filho, Elba Lúcia Cavalcanti de Amorim , Ivone Antonia de Souza, Ulysses Paulino de Albuquerque, Ednaldo Cavalcante de Araújo .Acute toxicity study of stone-breaker (Phyllanthus tenellus Roxb). Rev Ciênc Farm Básica Apl. 2012; 33(2):205-210.

3. Lui R-LH, Huang YL, McIntosh H. Genus Phyllanthus for chronic hepatitis B virus infection: A systemic review. Viral Hepatitis. 2003;8(5):358-366.

4. Akoègninou $A$, van der Burg WJ, van der Maesen LJG Flore Analytique du Bénin. Backhuys Publishers ; Wageningen: 2006. 1034.

5. Patel JR, Tripathi P, Sharma V, Chauhan NS, Dixit VK. Phyllanthus amarus: ethnomedicinal uses, phytochemistry and pharmacology a review. J Ethnopharmacol. 2011;138(2): 286-313. Doi: 10.1016/j. jep.2011.09.040

6. Povi LE, Kwashie EG, Amegnona A, Kodjo A, Serge M, Edmond E, Messanvi G. Toxicological assessment on extracts of Phyllanthus amarus Schum and Thonn. Scientific Research and Essay. 2008;3(9):410-415.

7. Naaz F, Javed S, Abdin MZ. Hepatoprotective effect of ethanolic extract of Phyllanthus amarus Schum. et Thonn. on aflatoxin B1-induced liver damage in mice. J Ethnopharmacol. 2007;113(3):503-509. Doi: 10.1016/j.jep.2007.07.017

8. Krithika R, Verma RJ. Mitigation of carbon tetrachloride-induced damage by Phyllanthus amarus in liver of mice. Acta Pol Pharm. 2009; 66 (4):439-444.

9. Anderson, Dibble MV, Turkki PR, Mitchell HS and Rynbergen HJ. Nutrition in Health and Disease 17th Edition, J.B. Lippincoott Company; East Washington, Philadelphia:1982.

10.WHO. Definition, Diagnosis and Classification of Diabetes Mellitus and its Complications Report of a WHO Consultation Part 1: Diagnosis and Classification of Diabetes Mellitus. Geneva; World Health Organization, Department of Noncommunicable Disease Surveillance: 1999.

11.Singh SK, Rai PK, Jaiswal D and Watal G. Evidence-Based Critical Evaluation of Glycemic Potential of Cynodon dactylon. Evidence-Based Complementary and Alternative. 2008;5:415-420. Doi: 10.1093/ ecam/nem044

12. National Diabetes Data Group. Classification and Diagnosis of Diabetes Mellitus and Other Categories of Glucose Intolerance. Diabetes. 1979;28(12):1039-1057.

13. Shaw JE, Sicree RA and Zimmet PZ. Global Estimates of the Prevalence of Diabetes for 2010 and 2030. Diabetes Research and Clinical Practice. 2010;87(1):4-14. Doi: 10.1016/j.diabres.2009.10.007

14. Girach A, Manner D and Porta M. Diabetic Microvascular Complications: Can Patients at Risk Be Identified? A Review. International Journal of Clinical Practice. 2006;60(11):1471-1483. Doi: 10.1111/j.17421241.2006.01175.x 
15. Aski Basavaraj S, Devarnavadagi BB, Rudrappa G, Kashinath, RT. Influence of Anti Diabetic Therapy on Plasma Lipid Profile and its Relation to Erythrocyte Membrane Lipid Levels in Type 2 Diabetic Subjects. Global Journal of Medical Research. 2012;12(11):1-9.

16. Haffner SM, Lehto S, Ronnemaa T, Pyrala K and Laakso M. Mortality from Coronary Heart Disease in Subjects with Type 2 Diabetes and in Nondiabetic Subjects with and without Prior Myocardial Infarction. The New England Journal of Medicine. 1998;339(4):229-234. Doi: 10.1056/NEJM199807233390404

17. Betteridge DJ. Diabetic Dyslipidemia. American Journal of Medicine. 1994;96(6):25-31. Doi: 10.1016/0002-9343(94)90228-3

18. Mayes PA and Botham, KM. Lipid Transport and Storage. Harper's Illustrated Biochemistry, 28th Edition, The McGraw-Hill Companies, Inc.; New York: 2009. 205-218.

19. Hayden, J.M. and Reaven, P.S. Cardiovascular Disease in Diabetes Mellitus Type 2: A Potential Role for Novel Cardio-Vascular Risk Factors. Current Opinion in Lipidology. 2000; 11: 519-528. Doi: 10.1097/00041433-200010000-00010

20. Bener A, Zirie M and Al-Rikkabi R. Genetics, Obesity and Environmental Risk Factors Associated with Type 2 Diabetes. Croatian Medical Journal. 2005;46(2):302-307.

21. Bazzano LA, Serdula, MK and Liu S. Dietary Intake of Fruits and Vegetables and Risk of Cardiovascular Disease. Current Atherosclerosis Reports 2003;5(6):492-499. Doi: 10.1007/s11883-003-0040-z

22. Schuster D, Laggner C and Langer T . Why Drugs Fail-A Study on Side Effects in New Chemical Entities. Current Pharmaceutical Design. 2005;11(27):3545-3559.

23. Braga TV, Rodrigues das Dores RG, Camila Soncin Ramos CS, Evangelista FCG, Tinoco LM, Varotti FP, et al. Antioxidant, Antibacterial and Antitumor Activity of Ethanolic Extract of the Psidium guajava Leaves. American Journal of Plant Sciences. 2014;5:3492-3500. Doi: 10.4236/ajps.2014.523365

24. López-Lázaro M. Distribution and Biological Activities of the Flavonoid luteolin. Mini Rev Med Chem. 2009;9(1):31-59.

25. Maharjan BL and Baral B. Antioxidant Capacity and Phenolic Content of Some Nepalese Medicinal Plants. American Journal of Plant Sciences. 2013;4:1660-1665. Doi: 10.4236/ajps.2013.48200

26. Liao K.-L \& Yin M-C. Individual and combined antioxidant effects of seven phenolic agents in human erythrocyte membrane ghosts and phosphatidylrcholine liposome systems: Importance of the partition coefficient. Journal of Agricultural and Food Chemistry. 2000;48(6):2266-2270. Doi:10.1021/jf990946w

27. Halliwell B, Aeschbach R, Löliger J and Aruoma OI. The characterization of antioxidants. Food Chemistry and Toxicology. 1995;33(7):601-617. Doi: 10.1016/0278-6915(95)00024-V

28. Tseng TH, Kao ES, Chu CY, Chou FP, Lin Wu HW and Wang CJ. Protective Effects of Dried Flower Extracts of Hibiscus sabdariffa L. against Oxidative Stress in Rat Primary Hepatocytes. Food Chemistry and Toxicology. 1997;35(12):1159-1164.

29. Soares JR, Dinis TCP, Cunha AP and Almeida LM. Antioxidant Activities of some Extracts of Thymus zygis. Free Radical Research. 1997;26(5):469-478.

30. Brown JE \& Rice-Evans CA. Luteolin-Rich Artichoke Extract Protects Low Density Lipoprotein from Oxidation in vitro. Free Radical
Research. 1998;29(3):247-255.

31. Gil MI, Ferreres F \& Tomás-Barberán F A. Effect of Postharvest Storage and Processing on the Antioxidant Constituents (Flavonoids and Vitamin C) of Fresh-Cut Spinach. Journal of Agricultural and Food Chemistry. 1999;47(6):2213-2217.

32. Kähkönen MP, Hopia AI, Vuorela HJ, Rauha JP, Pihlaja K, Kujala TS, et al. Antioxidant Activity of Plant Extracts Containing Phenolic Compounds. Journal of Agricultural and Food Chemistry. 1999;47(10):3954-3962.

33.Vinson JA, Dabbagh YA, Serry MM and Jang J. Plant Flavonoids, Especially Tea Flavonols, Are Powerful Antioxidants Using an in vitro Oxidation Model for Heart Disease. Journal of Agricultural and Food Chemistry. 1995;43:2800-2802. Doi: 10.1021/jf00059a005

34. Halliwell B. Oxidative stress, nutrition and health. Experimental strategies for optimization of nutritional antioxidant intake in humans. Free Radical Research. 1996;25(1):57-74.

35. Jayaprakash GK \& Rao LJ. Phenolic constituents from lichen Parmontrema stuppeum. Food Control. 2000;56:1018-1022.

36. Wagner H, Bladt S. Plant Drug Analysis. 2nd ed. Springer. 2001;P. 384.

37. Bruneton J. Pharmacognosie, Phytochimie, Plantes médicinales. 4th edition. Paris France. 2009; TEC DOC p. 456.

38. Li HB, Cheng KW, Wong CC, Fan KW, Chen F, Jiang Y. Evaluation of antioxidant capacity and total phenolic content of different fractions of selected microalgae. Food chemistry. 2007;102:771-776.

39. Nadhiya K, Vijayalakshmi K. Evaluation of total phenol, flavonoid contents and in vitro antioxidant activity of benincasa Hispida fruit extracts. International journal of pharmaceutical, chemical and biological sciences. 2014;4(2):332-338.

40. Broadhurst RB, Jones WT. Sci. Food Agr. 1978;29:788-794.

41. Heimler DP, Vignolini, Dini MG, Vincieri FF. Antiradical activity and polyphenol composition of local Brassicaceae edible varieties, Romani A. Food Chem. 2006;99(3):464-469.Doi: 10.1016/j. foodchem.2005.07.057

42. Velazquez E, Tournier HA, Mordujovich de Buschiazzo P, Saavedra G, Schinella GR. Antioxydant activity of Paraguayan plant extracts. Fitoterapia. 2003;74(1-2):91-97.

43. Pareek H, Sharma S, Khajja BS, Jain K, Jain GC. Evaluation of Hypoglycemic and Anti-Hyperglycemic Potential of Tridax procumbens (Linn.). BMC Complementary and Alternative Medicine. 2008;9:48. Doi:10.1186/1472-6882-9-48.

44. Crane RK, Sols A. The association of hexokinase with particulate fractions of brain and other tissue homogenates. J Biol Chem. 1953;203(1):273-292.

45. Bucher T, Pfleiderer G. Pyruvate kinase from muscle. Methods Enzymol. 1955;1:435-440.

46. Carroll NV, Longley RW, Roe JH. The determination of glycogen in liver and muscle by use of anthrone reagent. J Biol Chem. 1956;220(2):583593.

47. Koide H, Oda T. Pathological occurrence of glucose-6-phosphatase in serum in liver diseases. Clin Chim Acta. 1959;4:554-561.

48. Pontremoli S. Fructose-1,6-diphosphatase: I. Rabbit liver (crystalline). Methods Enzymol. 1966 ;9:625-631.

49. Singh VN, Venkatasubramanian TA, Viswanathan R. The glycolytic enzymes of guinea pig lung in experimental bagassosis. Biochem J. 1961;78(4):728-732. 
50. Nalini R \& Anuradha R. Phytochemical Screening and "In-Vitro" Antioxidant Activity of Ethanolic Flower Extracts of Punica granatum. Int J Pharm Sci Rev Res. 2015;30(1):353-360.

51. Shah R, Kathad H, Sheth R, Sheth N. In vitro antioxidant activity of roots of Tephosia purpurea Linn. Int. J Pharm. Sci. 2010;3(2):30-33.

52. Akhtar MS, Athar MA. and Yaqub M. Effect of Momordica charantic on blood glucose level of normal and alloxan-diadetic rabbits. Planta Medica. 1981;42(3):205-211.

53. Osadebe PO, Okide GB, Akabogu IC. Study on anti-diabetic activities of crude methanolic extracts of Loranthus micranthus (Linn.) sourced from five different host trees. J. Ethnopharmarcolog. 2004;95(23):133-135. Doi: 10.1016/j.jep.2004.06.029

54. Hasrat JA, De Bacher JP, Vauguelin A, Vlietinck AJ. Medicinal plants in Suriname: screening of plant extracts for receptorbinding activity. Phytomedicine.1997;4(1):59-65. Doi: 10.1016/S09447113(97)80029-3

55. Etukudo I. Ethnobotany, conventional and traditional uses of plants. The Verdict Press. Uyo, Akwa Ibom State. 2003;89- 90.

56. Oloyede OI. Chemical Profile of Unripe Pulp of Carica papaya. Parkistin jounal of Nutrition. 2005;4(6):379-381.

57. Torres JL, Rosazza JPN. Microbial transformations of p-coumaric acid by Bacillus megaterium and Curvularia lunata. J. Nat. Prod. 2001;64(11):1408-1414.

58. Naczk M, Shahidi F. Extraction and analysis of phenolics in food. J Chromatogr. 2004;1054(1-2):95-111. Doi: 10.1016/j. chroma.2004.08.059

59. Martin-Nizard F, Sahpaz S, Kandoussi A, Carpentier M, Fruchart JC, Duriez P. Natural phenylpropanoids inhibit lipoprotein induced endothelin-1 secretion by endothelial cells. J Pharm Pharmacol. 2004;56(12):1607-1611. Doi: 10.1211/0022357045048

60. Hunt J, Dean RT, Wolff SP. Hydroxyl radical production and autoxidative glycosylation glucose autoxidation as the cause of damage in the experimental glycation model of diabetes and ageing. Biochem J. 1988;256(1):205-212.

61. Martin-Nizard F, Sahpaz S, Furman C, Fruchart JC, Duriez P, Bailleul F. Natural phenylpropanoids protect endothelial cells against oxidized LDL-induced cytotoxicity. Planta Med . 2003;69(3):207-11. Doi: $10.1055 / \mathrm{s}-2003-38474$

62. Eidi A, Eidi M, Esmaeili E. Antidiabetic effect of garlic (Allium sativum L.) in normal and streptozotocin-induced diabetic rats. Phytomedicine. 2006;13(9-10):624-629. Doi: 10.1016/j.phymed.2005.09.010

63. Ohaeri OC. Effect of garlic oil on the levels of various enzymes in the serum and tissue of streptozotocin diabetic rats. Biosci Rep. 2001;21(1):19-24.

64. Yoon MA, Jeong TS, Park DS, Xu MZ, Oh HW, Song KB, et al. Antioxidant effects of quinoline alkaloids and 2,4-di-tert-butylphenol isolated from Scolopendra subspinipes. Biol Pharm Bull. 2006;29(4):735-739.

65. Constantino L, Parenti C, Di Bella M,Zanoli P, Baraldi M. Antiinflammatory activity of newly synthesized 2,6-bis-(1,1-dimethylethyl) phenol derivates. Pharmacol Res. 1993;27(4):349-358. Doi: 10.1006/ phrs.1993.1034

66. Piedrafita FJ, Ortiz MA. Mechanism of action and therapeutic potential of novel adamantyl retinoid-related molecules. Curr Cancer Ther Rev. 2006;2:185-198.
67. Singab AN, El-Beshbishy HA, Yonekawa M. Hypoglycaemic effect of Egyptian Morus alba root bark extract: Effect on diabetes and lipid peroxidation of streptozotocin-induced diabetic rats. J Ethanopharmacol. 2005;100(3):333-338. Doi; 10.1016/j. jep.2005.03.013

68. Altura BM \& Altura BT. Cardiovascular risk factors and magnesium: Relationships to atherosclerosis, ischemic heart disease and hypertension. Magnesium and Trace Elements. 1991;10(2-4):182192.

69. Eliza J, Daisy P, Ignacimuthub S, Duraipandiyan V. Antidiabetic and antilipidemic effect of eremanthin from Costus specious (koen) Sm. In STZ-induced diabetic rats. Chemico-Biological Interactions. 2009;182(1):67-72. Doi: 10.1016/j.cbi.2009.08.012

70. Eliza J, Rajalakshmi M, Ignacimuthu SJ Daisy P. Normalizing effects of Costus speciosus rhizome crude extracts and its fractions on diabetic complications in STZ-induced diabetic rats. Med Chem Res. 2011;20(7):1111-1118. Doi: 10.1007/s00044-010-9448-5

71. Metz E, Houghton A. Insulin receptor substrate regulation of phosphoinositide 3-kinase. Clin Cancer Res. 2011;17(2):206-211. Doi: 10.1158/1078-0432.CCR-10-0434

72. Hii CS, Howell SL. Effects of flavonoids on insulin secretion and Ca2+ handling in rat islets of Langerhans. J Endocrinol. 1985;107(1):1-8.

73. Bhavapriya V, Govidasamy S. Biochemical studies on the hypoglycemic effect of Aegle marmelos (Linn). Correa Ex. RoxB. In streptozotocin induced diabetic rats. Indian Drugs. 2000;37(10):474-477.

74. Xu J, Christian B, Jump DB. Regulation of rat hepatic L-pyruvate kinase promoter composition and activity by glucose, n-3polyunsaturated fatty acids, and peroxisome proliferators-activated receptor-alpha agonist. J Biol Chem. 2006;281(27):18351-18362. Doi: 10.1074/jbc. M601277200

75. Yamada, K. \& Noguchi, T. Nutrient and hormonal regulation of pyruvate kinase gene expression. Biochemical Journal. 1999;337:1-11.

76. Taylor, R. \& Agius, L. The biochemistry of diabetes. Biochemical Journal. 1988;250:625-640.

77. Grover JK, Vats V, Rathi SS. Anti-hyperglycaemic effect of Eugenia jambolana and Tinospora cordifolia in experimental diabetes and their effects on key metabolic enzymes involved in carbohydrate metabolism. J Ethnopharmacol. 2000;73(3):461-470.

78. Baquer NZ, Gupta D, Raju J. Regulation of metabolic pathways in liver and kidney during experimental diabetes. Indian J Clin Biochem. 1998;13(2):63-80. Doi: 10.1007/BF02867866

79. Pederson BA, Schroeder JM, Parker GE, Smith MW, DePaoli-Roach AA, Roach PJ. Glucose metabolism in mice lacking muscle glycogen synthase. Diabetes. 2005;54(12):3466-3473.

80. Golden S, Wals PA, Okajima F. Glycogen synthesis by hepatocytes from diabetic rats. Biochem J. 1979;182:727-734.

81. Alkaladi A, Abdelazem A, Afifi M. Antidiabetic activity of zinc oxide and silver nanoparticles on streptozotocin-induced diabetic rats. Int J Mol Sci. 2014; 15: 2015-2023.

82.Zhang X, Wenbo L, Yiqing M, Hui L, Yang Y, Huanran T. Hepatic glucokinase activity is the primary defect in alloxaninduced diabetes of mice. Biomed Pharmacother. 2009;63(3):180-186. Doi: 10.1016/j. biopha.2007.07.006

83. Tahrani A, Milan K, Amy K, Anthony H. Glycaemic control in 
type 2 diabetes: Targets and new therapies. Pharmacol Ther. 2010;125(2):328-361. Doi: 10.1016/j.pharmthera.2009

84.Samir D,Abbas K, Djermoune M, Ben-AMARA Zine K. the effects of copper supplement on zine status, enzymes of zinc activities and antioxidant status in alloxan-induced diabetic rats fed on zinc over-dose diet. International journal of Nutrition and Metabolism. 2013;5(5):82-87. Doi: 10.5897/IJNAM2013.0150

85. Rowe C, Jiang A, Arany Z. PGC-1 Coactivators in Cardiac Development and Disease. Circ Res. 2010;107(7):825-838. Doi: 10.1161/ CIRCRESAHA.110.223818

86. Binny K, Kumar SG, Dennis T. Anti-inflammatory and antipyretic properties of the rhizome of Costus speciosus (Koen.)SM. J Basic Clin Pharm. 2010;1(3):177-181.

87. Sadasivan S, Vasamsetti B, Singh J, Siddaraju N, Khan K, OommenA. Modulation of de novo purine biosynthesis leads to activation of AMPK and results in improved glucose handling and insulin sensitivity. J Diabetes Metab Disord. 2014;13:1-9. Doi: 10.1186/2251-6581-13-51
88. El-Far AH, Abou-Ghanema I. Biochemical and hematological evaluation of Costus speciosus as a dietary supplement to Egyptian buffaloes. Afr J Pharm Pharmacol. 2014;7(42):2774-2779.

89. Vats V, Yadav SP \& Grover JK. Ethanolic extract of Ocimum sanctum leaves partially attenuates streptozotocin-induced alterations in glycogen content and carbohydrate metabolism in rats. Journal of Ethnopharmacolology. 2004; 90(1):155-160. Doi: 10.1016/j. jep.2003.09.034

90. Freitas HS, Schaan BD, Seraphim PM, Nunes MT, Machado UF. Acute and short-term insulin-induced molecular adaptations of GLUT2 gene expression in the renal cortex of diabetic rats. Endocrinology. 2005;237:49-57. Doi: 10.1016/j.mce.2005.03.005

91. Csont T, Balogh G, Csonka C, Boros I, Horva I,Vigh L, Ferdinandy P. Hyperlipidemia induced by high cholesterol diet inhibits heat shock response in rat hearts. Biochemical ad Biophysical Research Communicatios. 2002;290:1535-1538. Doi: 10.1006/bbrc.2002.6377 